\title{
Analysis of the Quality of Stabilized Municipal Sewage Sludge
}

\author{
Izabela Bartkowska'*, Paweł Biedka', Izabela Anna Tałałaj' \\ 1 Bialystok University of Technology, Department of Technology and Environmental Engineering Systems, \\ ul. Wiejska 45 A, 15-351 Bialystok, Poland \\ * Corresponding author's e-mail: i.bartkowska@pb.edu.pl
}

\begin{abstract}
The sludge management of many wastewater treatment plants in Poland has not been properly solved yet. The exploiters and designers often have to cope with the dilemma of choosing the method of processing and neutralizing sewage sludge. The method discussed in the article is only one of the options that fully fits in the trends of implementing good practices in the management of sewage sludge. It is a technologically and economically effective as well as environmentally friendly process. It contributes significantly to minimizing the amount of sewage sludge and allows the production of organic fertilizer instead of waste. The work discusses the quality of sewage sludge after autothermal thermophilic stabilization (ATAD). The results of investigations pertaining to the reaction of sludge, dry mass, dry organic matter, content of biogenic substances, calcium and magnesium compounds and heavy metals were analyzed.
\end{abstract}

Keywords: autothermal thermophilic aerobic digestion, digestion of sludge, natural utilization of sludge, sludge

\section{INTRODUCTION}

The construction of new wastewater treatment plants, the modernization of existing ones, and in particular the use of highly effective methods of wastewater treatment have resulted in an increase in the amount of deposits. Depending on the sewage treatment technology in the treatment plant, pre-sludges may be formed from pre-treatment, excessive sludge from biological treatment and deposits from chemical treatment (Heidrich and Suszyński, 2010). The resulting sludge requires disposal for legal, aesthetic and practical reasons. The economic and ecological considerations require that sludge, if possible, should be recycled back into the natural environment. This is still the cheapest method for the final disposal of sewage sludge. However, the natural use is only possible if they are stable, sanitary safe, and will not contain excessive concentrations of heavy metals.

There are many known methods for the stabilization and hygienization of sewage sludge. There are even more technologies based on them and devices/installations used to implement them. The most popular choice in Europe is the thermal processing of sewage sludge. However, under domestic/country conditions, undoubtedly the most preferred option, especially for a certain size of sewage treatment plants, is their natural use (Podedworna and Heidrich, 2010).

The ideal solution may be autothermal thermophilic stabilization (ATAD). Unfortunately, this process is still not well known in Poland; it enables to obtain organic fertilizer instead of waste in sewage treatment plants.

The purpose of this article is to present the results of the analysis pertaining to the quality of municipal sewage sludge that is subjected to the ATAD process. The utilitarian purpose is to demonstrate the usefulness of the sludge under investigation for its natural use as a method of its final disposal.

The carried out review and evaluation of research results will serve to make people aware that in accordance with the sustainable development assumptions, the sewage sludge produced in these sewage treatment plants should be treated as a source of recovery for the main nutrients of plants and not as waste. 


\section{MATERIALS AND METHODS}

The studies on municipal sewage sludge were conducted in 2014-2016. They concerned the sludge stabilized through the ATAD process and dehydrated. From among 11 ATAD installations working in the country, the results of tests from 7 sewage treatment plants were analyzed, as the others have already received the decision of the Minister of Agriculture and Rural Development for the introduction of organic fertilizer from the generated sludge to the market. In the case of two sewage treatment plants, the test results concern a shorter period, as the ATAD installations were implemented there in 2015.

\section{Sewage sludge}

The municipal sewage sludge processed in a two- or three-stage autothermal thermophilic stabilization plant was analyzed. The total residence time of sludge in the installation ranged from 7.3 to 9.3 days. The capacity of the installations in question varied from $16.7 \mathrm{~m}^{3} / \mathrm{d}$ to $70 \mathrm{~m}^{3} / \mathrm{d}$. Sludge deposits or a mixture of initial and excessive sludge sediments were stabilized. The sludge was collected for analysis after dehydration.

\section{Sampling and analyses}

The sewage sludge samples for testing were collected in accordance with PN - EN ISO 5667 - 13: 2011 standard. A representative sample was obtained by combining and thoroughly mixing a certain number of samples, taken at the same time from different places of the same in- stallation, in accordance with the Regulation of the Minister of Environment of 6 February 2015 on municipal sewage sludge.

The determinations required for the annual, collective data tabulations of data for the generated municipal sewage sludge were analysed. These include: $\mathrm{pH}$, content of dry mass and organic substances, total and ammonia nitrogen, total phosphorus, calcium, magnesium and heavy metals (cadmium, copper, nickel, lead, zinc, mercury and chromium). In addition, the information on the content of live parasitic eggs and Salmonella bacteria is required. All determinations were made in accordance with the reference test methods indicated in the Regulation of the Minister of Environment of 6 February 2015 on municipal sewage sludge.

\section{RESULTS AND DISCUSSION}

\section{Hydrogen ion exponent}

The $\mathrm{pH}$ of the ATAD treated sludge changes from slightly acidic to slightly alkaline. In the period under study and analysis, it changed from a minimum of $6.5 \mathrm{pH}$ to a maximum of $8.8 \mathrm{pH}$. The most commonly observed value was $\mathrm{pH}$ equal to 7.9 . Only $10 \%$ of the values indicated a slightly acidic $\mathrm{pH}$ of the sludge. The range of values in individual wastewater treatment plants, named with subsequent letters of the alphabet, is shown in Fig.1.

Similar values of $\mathrm{pH}$ were observed in the previous studies, the results of which were presented by Bartkowska (2013; 2014; 2015). The chang-

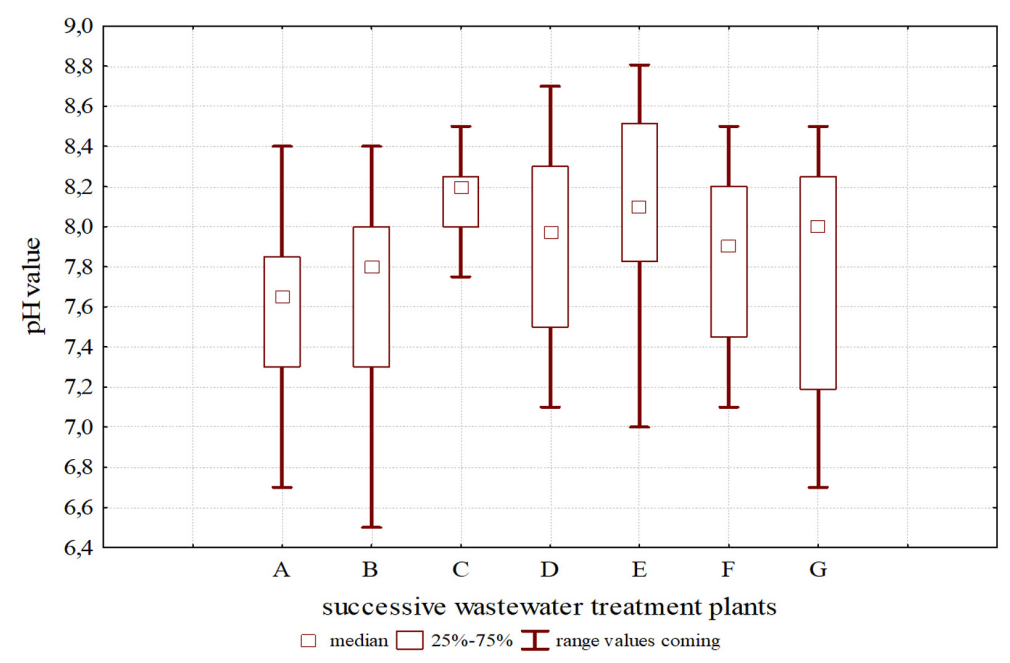

Fig. 1. Range of sludge reaction values for the analyzed wastewater treatment plants 
es in sludge $\mathrm{pH}$ due to the thermophilic process of their stabilization, in the available literature, show a comparable range of values. The most frequent increase in $\mathrm{pH}$ is from $6.3 \mathrm{pH}$ for crude sludge to $9.1 \mathrm{pH}$ for stabilized sludge (Nosrati et al., 2007; Parsons, 2008; Piterina et al., 2010a). Fewer changes range from $\mathrm{pH} 7.0$ for the sludge before the ATAD process to $\mathrm{pH} 8.2$ for the sludge after the process (Zhou et al., 2002; Movahedian et al., 2005) are also reported. According to Kelly (2006) and Zupančič and Ros (2008), the absolute values of the increase in the $\mathrm{pH}$ of sludge caused by the ATAD process are usually $1 \div 2 \mathrm{pH}$ units.

\section{The content of dry mass and organic substances}

The dry mass content in the stabilized sewage sludge depends to a large extent on the dewatering device used. The adopted solution of sludge management and correct operation of the devices used are of great importance. The content of dry mass of sewage sludge within the period under study ranged from $10.4 \%$ to $35.0 \%$. Table 1 presents the numerical characteristics of the distribution of dry matter content in the analyzed sewage sludge.

The content of the organic fraction in the dry mass of sludge is determined by the effectiveness of the stabilization process. The stabilized sludge examined in the period of analyses contained from $29 \%$ to $59.4 \%$ of organic substances in the dry mass. Table 2 presents the numerical charac- teristics of the distribution of organic matter content in the dry mass of sewage sludge.

The process of autothermal thermophilic stabilization of sewage sludge reduces the content of readily decomposable organic substances. Many years of research conducted in the sewage treatment plants with ATAD installations confirmed that the average decrease in organic matter in the dry mass of sludge is greater than the required $38 \%$. This observation was documented by Bartkowska (2013; 2015).

\section{Biogenic compounds}

The term biogenic compounds should be understood as the elements and mineral salts needed for the development of plant and animal organisms. The content of nitrogen and phosphorus compounds in sludge is important. Their presence is particularly desirable in the case of natural use of sludge. In the investigated sludge the content of total and ammonium nitrogen as well as total phosphorus was analyzed. Table 3 presents the numerical characteristics pertaining to the distribution of nitrogen and phosphorus compounds in the dry mass of the sewage sludge under study.

The content of total nitrogen in the period under study was from the minimum value of $2.43 \%$ of dry mass to the maximum of $7.58 \%$ of dry mass. The ammonia nitrogen content in the total amount of nitrogen changed from 0.11 to $1.82 \%$ of dry mass. In the sewage sludge after the auto-

Table 1. Numerical characteristics of the analyzed dry matter content distribution (\%)

\begin{tabular}{|l|c|c|c|c|c|c|c|}
\hline \multirow{2}{*}{\multicolumn{1}{c}{ Distribution measure }} & \multicolumn{5}{c|}{$\begin{array}{c}\text { The values of the distribution measures calculated for the test results } \\
\text { in subsequent wastewater treatment plants }\end{array}$} \\
\cline { 2 - 8 } & A & B & C & D & E & F & G \\
\hline Arithmetic mean & 19.25 & 21.96 & 22.05 & 30.47 & 15.43 & 25.17 & 23.02 \\
\hline Maximum & 22.00 & 30.40 & 28.00 & 35.00 & 19.90 & 32.60 & 27.50 \\
\hline Minimum & 16.40 & 15.50 & 16.50 & 22.30 & 10.40 & 19.70 & 17.80 \\
\hline Variance & 3.80 & 20.90 & 11.83 & 31.73 & 7.99 & 44.50 & 23.93 \\
\hline Standard deviation & 1.95 & 4.57 & 3.44 & 5.63 & 2.83 & 6.67 & 4.89 \\
\hline
\end{tabular}

Table 2. Numerical characteristics of the analyzed content distribution of organic matter in dry matter (\%)

\begin{tabular}{|c|c|c|c|c|c|c|c|}
\hline \multirow[t]{2}{*}{ Distribution measure } & \multicolumn{7}{|c|}{$\begin{array}{l}\text { The values of the distribution measures calculated for the test results in subsequent } \\
\text { wastewater treatment plants }\end{array}$} \\
\hline & A & B & $\mathrm{C}$ & $\mathrm{D}$ & $E$ & $\mathrm{~F}$ & $\mathrm{G}$ \\
\hline Arithmetic mean & 51.91 & 49.64 & 51.61 & 53.28 & 52.82 & 54.20 & 56.70 \\
\hline Maximum & 57.20 & 57.70 & 59.00 & 59.03 & 59.00 & 59.40 & 58.20 \\
\hline Minimum & 43.00 & 37.90 & 29.00 & 51.80 & 47.40 & 49.20 & 55.30 \\
\hline Variance & 27.03 & 30.80 & 129.82 & 6.80 & 15.28 & 26.04 & 2.11 \\
\hline Standard deviation & 5.20 & 5.55 & 11.39 & 2.61 & 3.91 & 5.10 & 1.45 \\
\hline
\end{tabular}


Table 3. Numerical characteristics of the analyzed distributions of total, ammonium and total phosphorus content in the dry mass of sludge

\begin{tabular}{|c|c|c|c|c|c|c|c|}
\hline \multirow{2}{*}{ Distribution measure } & \multicolumn{7}{|c|}{$\begin{array}{l}\text { The values of the distribution measures calculated for the test results in subsequent } \\
\text { wastewater treatment plants }\end{array}$} \\
\hline & $A$ & B & $\mathrm{C}$ & $\mathrm{D}$ & $E$ & $\mathrm{~F}$ & $\mathrm{G}$ \\
\hline \multicolumn{8}{|c|}{ Total nitrogen content ( $\%$ dry mass) } \\
\hline Arithmetic mean & 5.09 & 4.39 & 5.27 & 3.63 & 4.61 & 5.77 & 6.53 \\
\hline Maximum & 7.58 & 5.62 & 6.94 & 4.40 & 5.16 & 6.20 & 6,75 \\
\hline Minimum & 3.91 & 2.82 & 4.15 & 2.43 & 4.06 & 5.30 & 6.30 \\
\hline Variance & 1.02 & 0.49 & 0.66 & 0.75 & 0.13 & 0.20 & 0.05 \\
\hline Standard deviation & 1.01 & 0.70 & 0.82 & 0.87 & 0.36 & 0.45 & 0.23 \\
\hline \multicolumn{8}{|c|}{ Ammonia nitrogen content ( $\%$ dry mass) } \\
\hline Arithmetic mean & 0.48 & 0.57 & 1.08 & 0.53 & 0.76 & 0.78 & 1.02 \\
\hline Maximum & 0.90 & 0.99 & 1.82 & 0.79 & 1.52 & 0.91 & 1.26 \\
\hline Minimum & 0.31 & 0.33 & 0.11 & 0.39 & 0.22 & 0.64 & 0.79 \\
\hline Variance & 0.03 & 0.04 & 0.24 & 0.04 & 0.14 & 0.02 & 0.06 \\
\hline Standard deviation & 0.17 & 0.19 & 0.49 & 0.19 & 0.37 & 0.14 & 0.24 \\
\hline \multicolumn{8}{|c|}{ Total phosphorus content (\% dry mass) } \\
\hline Arithmetic mean & 2.92 & 3.23 & 3.31 & 2.75 & 2.68 & 3.17 & 2.39 \\
\hline Maximum & 3.80 & 4.22 & 5.60 & 3.68 & 3.22 & 3.50 & 3.00 \\
\hline Minimum & 2.28 & 2.11 & 1.07 & 1.70 & 2.17 & 2.90 & 1.58 \\
\hline Variance & 0.19 & 0.39 & 1.94 & 0.66 & 0.13 & 0.09 & 0.53 \\
\hline Standard deviation & 0.43 & 0.62 & 1.39 & 0.81 & 0.36 & 0.31 & 0.73 \\
\hline
\end{tabular}

thermal thermophilic stabilization, the total phosphorus content total ranged from 1.07 to $5.60 \%$ dry mass. Figure 2 shows the average content of total and ammonia nitrogen as well as total phosphorus in individual wastewater treatment plants.

Antolin et al. (2010) studied the sewage sludge subjected to the ATAD process, in which the average total nitrogen content was $8.6 \%$ of dry mass and ammonium nitrogen $1.3 \%$ of dry mass. Other researchers indicate that the source of nitrogen compounds primarily involves decomposed organic compounds, mainly proteins to amino acids. However, significant amounts of them go to the reflux (eluate) in the process of dewatering. In addition, high temperature and elevated reaction favour the transfer of ammonia nitrogen in the form of ammonia to air (Borowski, 2000; Zupančič and Roš, 2008).

During stabilization, due to the process of hydrolysis and mineralization of organic polymers, phosphorus, like nitrogen, but to a lesser extent, is released into the sludge liquid (Borowski, 2000). According to Antolin et al. (2010), the content of total phosphorus in the sludge after the ATAD process in the sewage treatment plant in Tudela (Spain) amounted to an average of $3.4 \%$ of dry mass.

\section{Calcium and magnesium}

Calcium and magnesium also belong to the group of elements the presence of which in or-

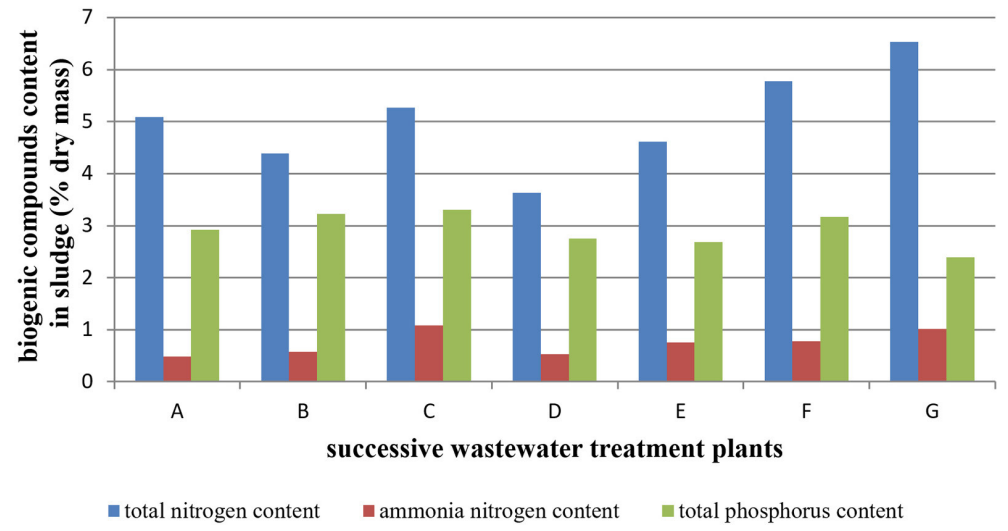

Fig. 2. The average values of biogenic compounds content in the analyzed sewage sludge 
ganic fertilizers obtained from sewage sludge is significant. They participate in shaping the fertility of soils. Their role consists mainly in influencing the physical properties of the soil. Magnesium is also a nutrient of plants. Table 4 presents the numerical characteristics of the distribution of calcium and magnesium content in the dry mass of the sewage sludge under study.

The calcium content in the tested sludge ranged from $1.60 \%$ DM to $8.80 \%$ of dry mass. On the other hand, the magnesium content changed from the minimum value of $0.08 \%$ dry mass to the maximum value of $1.31 \%$ dry mass. The average values of calcium and magnesium content in the sewage sludge from subsequent wastewater treatment plants are shown in Figure 3.

There is little information in the literature about the content of calcium and magnesium in the sewage sludge after autothermal thermophilic stabilization process ATAD. According to Antolin et al. (2010), the calcium content in the sludge after the ATAD process was on the average $4.3 \%$ dry mass and magnesium $0.8 \%$ dry mass.

\section{Heavy metals}

Sewage sludge can contain various amounts of heavy metals. Their presence depends primarily on the share of industrial wastewater in the total amount of wastewater subjected to the purification process. Table 5 presents the numerical characteristics of the heavy metal content distribution in the dry mass of the investigated sewage sludge.

In each of the objective wastewater treatment plants, the content of individual heavy metal during the period under analysis remained at a similar level. There was no significant variation in the content of these heavy metals in individual

Table 4. Numerical characteristics of the analyzed distributions of calcium and magnesium content in the dry mass of sludge

\begin{tabular}{|c|c|c|c|c|c|c|c|}
\hline \multirow{2}{*}{ Distribution measure } & \multicolumn{7}{|c|}{$\begin{array}{l}\text { The values of the distribution measures calculated for the test results in subsequent } \\
\qquad \text { wastewater treatment plants }\end{array}$} \\
\hline & A & B & $\mathrm{C}$ & D & $E$ & $\mathrm{~F}$ & G \\
\hline \multicolumn{8}{|c|}{ Calcium content ( $\%$ of dry mass) } \\
\hline Arithmetic mean & 5.28 & 4.81 & 5.66 & 3.79 & 3.52 & 3.53 & 3.95 \\
\hline Maximum & 8.40 & 8.35 & 8.80 & 4.63 & 4.70 & 4.20 & 5.00 \\
\hline Minimum & 3.49 & 1.60 & 2.87 & 2.90 & 2.48 & 2.90 & 2.69 \\
\hline Variance & 2.51 & 2.60 & 3.83 & 0.50 & 0.39 & 0.42 & 1.37 \\
\hline Standard deviation & 1.58 & 1.61 & 1.96 & 0.71 & 0.63 & 0.65 & 1.17 \\
\hline \multicolumn{8}{|c|}{ Magnesium content ( $\%$ of dry mass) } \\
\hline Arithmetic mean & 0.68 & 0.73 & 0.61 & 0.87 & 0.88 & 0.97 & 0.49 \\
\hline Maximum & 1.23 & 0.96 & 0.90 & 1.31 & 1.20 & 1.20 & 0.50 \\
\hline Minimum & 0.46 & 0.39 & 0.08 & 0.36 & 0.54 & 0.71 & 0.47 \\
\hline Variance & 0.05 & 0.02 & 0.12 & 0.16 & 0.03 & 0.06 & 0.01 \\
\hline Standard deviation & 0.23 & 0.15 & 0.35 & 0.40 & 0.18 & 0.25 & 0.10 \\
\hline
\end{tabular}

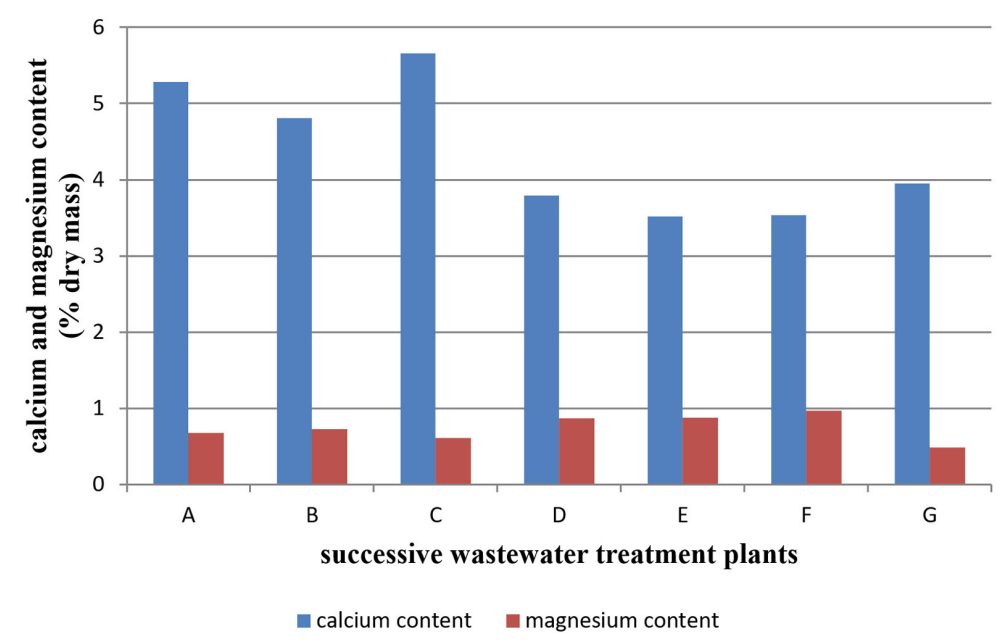

Fig. 3. Average values of calcium and magnesium content in the analyzed sewage sludge 
Table 5. Numerical characteristics of the analyzed heavy metal distributions in the dry mass of sludge

\begin{tabular}{|c|c|c|c|c|c|c|c|}
\hline \multirow{2}{*}{ Distribution measure } & \multicolumn{7}{|c|}{$\begin{array}{l}\text { The values of the distribution measures calculated for the test results in subsequent } \\
\text { wastewater treatment plants }\end{array}$} \\
\hline & A & B & C & D & $\mathrm{E}$ & $\mathrm{F}$ & G \\
\hline \multicolumn{8}{|c|}{ Cadmium content (mg/kg of dry mass) } \\
\hline Arithmetic mean & 1.91 & 2.28 & 1.33 & 2.12 & 1.56 & 1.39 & 1.64 \\
\hline Maximum & 5.54 & 3.09 & 1.45 & 2.77 & 2.66 & 1.80 & 2.14 \\
\hline Minimum & 1.14 & 0.25 & 1.13 & 1.10 & 0.25 & 0.97 & 1.06 \\
\hline Variance & 1.62 & 0.56 & 0.01 & 0.55 & 0.42 & 0.17 & 0.30 \\
\hline Standard deviation & 1,27 & 0.75 & 0.09 & 0.74 & 0.64 & 0.42 & 0.55 \\
\hline \multicolumn{8}{|c|}{ Copper content (mg/kg of dry mass) } \\
\hline Arithmetic mean & 331.97 & 287.26 & 209.17 & 203.52 & 529.43 & 312.67 & 298.25 \\
\hline Maximum & 548.00 & 394.00 & 343.00 & 283.00 & 806.00 & 371.00 & 356.00 \\
\hline Minimum & 268.00 & 107.00 & 68.00 & 91.00 & 333.00 & 238.00 & 235.00 \\
\hline Variance & 6645.67 & 6540.96 & 6566.75 & 7024.15 & 16545.89 & 4622.33 & 3682.94 \\
\hline Standard deviation & 81.52 & 80.88 & 81.04 & 83.81 & 128.63 & 67.99 & 60.69 \\
\hline \multicolumn{8}{|c|}{ Nickel content (mg/kg of dry mass) } \\
\hline Arithmetic mean & 33.01 & 24.18 & 16.65 & 14.63 & 47.25 & 13.37 & 15.31 \\
\hline Maximum & 53.00 & 31.40 & 24.00 & 19.80 & 59.70 & 18.00 & 17.70 \\
\hline Minimum & 18.60 & 9.44 & 11.00 & 8.60 & 35.00 & 8.90 & 12.90 \\
\hline Variance & 118.61 & 32.50 & 15.85 & 23.63 & 86.05 & 20.72 & 6.76 \\
\hline Standard deviation & 10.89 & 5.70 & 3.98 & 4.86 & 9.28 & 4.55 & 2.40 \\
\hline \multicolumn{8}{|c|}{ Lead content (mg/kg of dry mass) } \\
\hline Arithmetic mean & 34.67 & 52.92 & 17.63 & 22.25 & 44.63 & 12.47 & 20.94 \\
\hline Maximum & 51.40 & 162.00 & 27.10 & 29.60 & 61.10 & 19.00 & 23.80 \\
\hline Minimum & 26.80 & 22.10 & 10.10 & 8.58 & 30.90 & 4.70 & 18.20 \\
\hline Variance & 49.19 & 1704.33 & 25.01 & 50.81 & 111.24 & 52.26 & 7.85 \\
\hline Standard deviation & 7.01 & 41.28 & 5.00 & 7.13 & 10.55 & 7.23 & 2.80 \\
\hline \multicolumn{8}{|c|}{ Zinc content (mg/kg of dry mass) } \\
\hline Arithmetic mean & 716,34 & 1458,62 & 1395,89 & 813,10 & 1233,41 & 1110,67 & 1007,33 \\
\hline Maximum & 905,00 & 1903,00 & 2396,00 & 944,00 & 1633,00 & 1358,00 & 1072,00 \\
\hline Minimum & 555,00 & 637,00 & 328,00 & 677,00 & 893,00 & 865,00 & 950,00 \\
\hline Variance & 11888,20 & 128106,90 & 300698,00 & 14468,80 & 41803,90 & 60764,30 & 3761,30 \\
\hline Standard deviation & 109.03 & 357.92 & 548.36 & 120.29 & 204.46 & 246.50 & 61.33 \\
\hline \multicolumn{8}{|c|}{ Mercury content (mg/kg of dry mass) } \\
\hline Arithmetic mean & 0.75 & 0.80 & 0.60 & 0.41 & 7.14 & 2.52 & 1.54 \\
\hline Maximum & 1.16 & 1.65 & 1.20 & 0.60 & 9.30 & 5.00 & 3.00 \\
\hline Minimum & 0.34 & 0.39 & 0.19 & 0.19 & 1.50 & 0.57 & 0.27 \\
\hline Variance & 0.07 & 0.09 & 0.09 & 0.03 & 5.43 & 5.11 & 1.89 \\
\hline Standard deviation & 0.26 & 0.30 & 0.29 & 0.16 & 2.33 & 2.26 & 1.38 \\
\hline \multicolumn{8}{|c|}{ Chromium content (mg/kg of dry mass) } \\
\hline Arithmetic mean & 258.26 & 33.06 & 25.81 & 43.38 & 67.36 & 17.33 & 35.68 \\
\hline Maximum & 448.00 & 41.50 & 44.85 & 70.50 & 90.90 & 23.00 & 41.80 \\
\hline Minimum & 75.90 & 14.10 & 14.40 & 13.00 & 49.40 & 12.00 & 30.10 \\
\hline Variance & 11522.27 & 62.25 & 86.24 & 619.22 & 207.73 & 30.33 & 34.44 \\
\hline Standard deviation & 107.34 & 7.89 & 9.29 & 24.88 & 14.41 & 5.51 & 5.87 \\
\hline
\end{tabular}

wastewater treatment plants. In addition, it was smaller than the permissible content in relation to the sludge used in agriculture and land reclamation for agricultural purposes. The content of individual heavy metal in the tested sludge can be ranked according to their decreasing amounts, i.e. as follows: $\mathrm{Zn}>\mathrm{Cu}>\mathrm{Cr}>\mathrm{Pb}>\mathrm{Ni}>\mathrm{Cd}>\mathrm{Hg}$. There was also no downward trend or increase in the content of heavy metals in the sludge. The average values of heavy metal content in the sewage sludge from subsequent wastewater treatment plants are shown in Figure 4.
Similar amounts of heavy metals in sewage sludge were obtained by Antolin et al. (2010). The average cadmium content according to them was $<3 \mathrm{mg} / \mathrm{kg}$ dry mass, copper $275 \mathrm{mg} / \mathrm{kg}$ dry mass, nickel $41 \mathrm{mg} / \mathrm{kg}$ dry mass, lead $50 \mathrm{mg} / \mathrm{kg}$ dry mass, zinc $940 \mathrm{mg} / \mathrm{kg}$ dry mass and chromium $128 \mathrm{mg} / \mathrm{kg}$ dry mass.

\section{Microbiology and parasitology}

The microscopic analysis of the sludge subjected to the autothermal thermophilic stabiliza- 


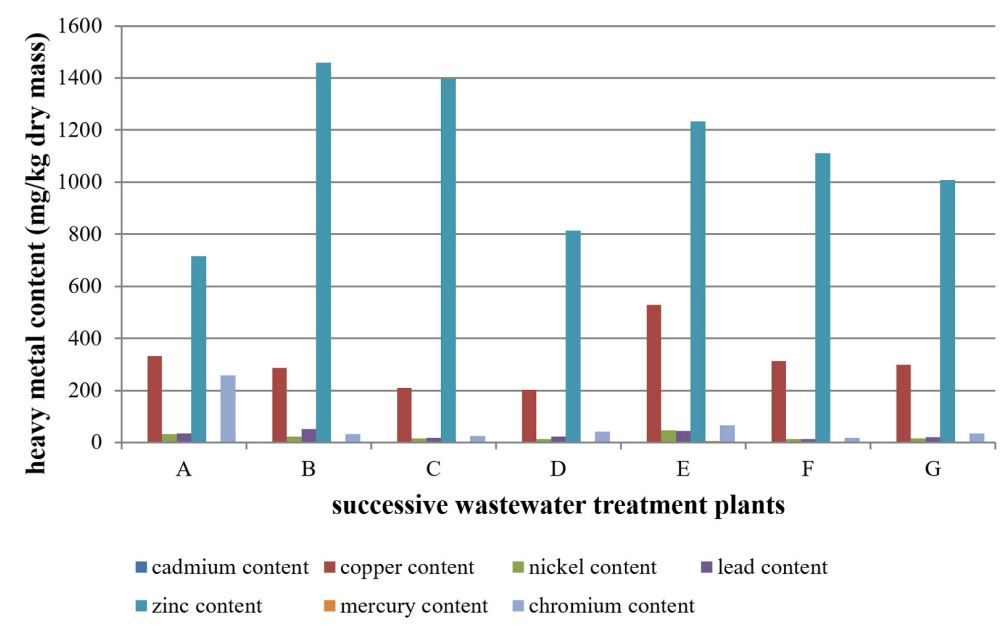

Fig. 4. The average values of heavy metal content in the analyzed sewage sludge

tion shows the presence of a fairly homogeneous microflora. However, from the point of view of the possibility of natural use of sewage sludge, the presence of pathogenic organisms is important. Testing the presence of indicator microorganisms in the sludge after the ATAD process is also a measure of the effectiveness of this process. In the investigated period, microbiological analyses of stabilized and dehydrated sludge was performed repeatedly. These analyses did not show the presence of live parasitic eggs. Salmonella species was not isolated. The presence of specific Salmonella DNA was not found either.

\section{Quantitative characteristics}

All wastewater treatment plants in which the tests were conducted operate the ATAD installation. They are sewage treatment plants of various sizes, in which the average annual mass of sludge produced ranges from 199.9 to $1838.2 \mathrm{Mg}$.
Figure 5 presents the amounts of sewage sludge produced in these municipal sewage treatment plants and these amounts were compared with the amount of natural sewage used for natural purposes in the analyzed period.

The sludge produced in objective wastewater treatment plants is used for natural purposes in $95-100 \%$.

\section{CONCLUSIONS}

1. Municipal sewage sludge has high fertilizing and soil-forming properties (Skowron et al., 2011). The sludge subjected to the autothermal process of thermophilic stabilization is also safe in terms of hygiene and sanitation. The presented research results, their analysis and evaluation support the natural use of sludge after ATAD. This is confirmed by the fact that three of the sewage treatment plants operating

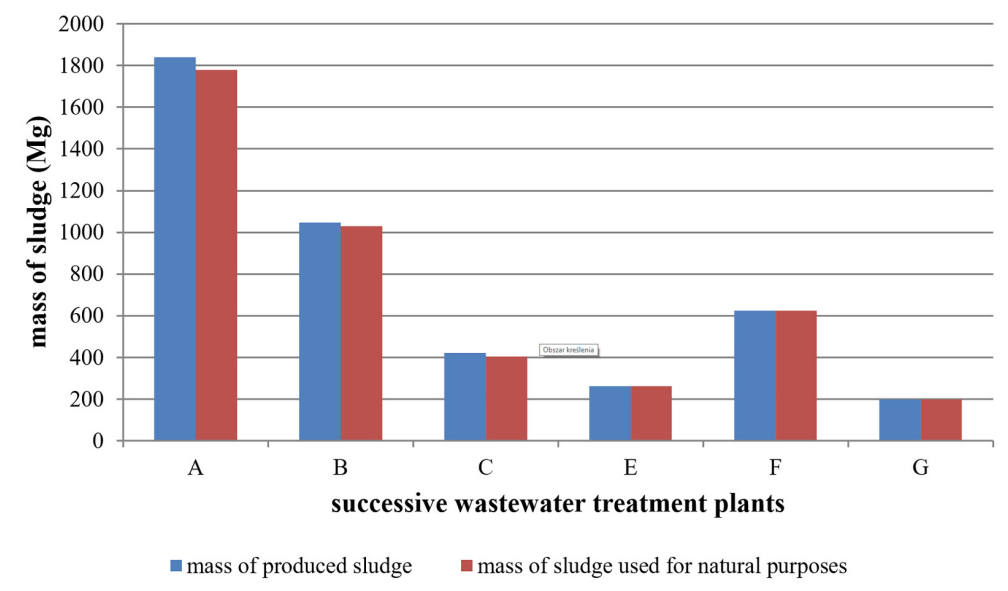

Fig. 5. Mass of sewage sludge produced and used for natural purposes in the sewage treatment plants under study 
at ATAD obtained the decision on the introduction of organic fertilizer from the generated sludge onto the market.

2. The quality of the discussed sludge meets the requirements set by the Regulation of the Minister of the Environment of February 6, 2015 on municipal sewage sludge. Sewage sludge and its microbiological transformation products have a positive effect on the physical, chemical and biological properties of soils. Their natural use mitigates the problem of high costs of mineral fertilization. The macro- and micro-nutrients contained in the sewage sludge are well absorbed by plants, and the full-value organic matter contained in them contributes to the improvement of the balance of humus compounds. Restoring the soil components collected in sewage sludge is appropriate not only from the economic point of view, but also necessary to maintain and restore the ecological balance. Sewage sludge can therefore be an excellent substitute for mineral fertilizers, which, in addition to being able to generate additional ecological problems, also contribute to considerable investment costs.

3. However, it should be remembered that the natural use of sewage sludge is possible if the appropriate legal requirements are met in terms of their quality, application method and the area of land on which they can be disposed of. In addition, the level of heavy metals in sludge may fluctuate. Therefore, sewage sludge should be regularly examined in terms of dynamics of changes in its chemical composition and biological parameters. These are the factors that increase the risk and limit the use of sludge in this way.

4. The experience gained so far, resulting from the 15-year period of research conducted with deposits subjected to the ATAD process and operation of the said installations, allow to state that this is a process that fully matches the trends of implementation of good practices in the sewage sludge management. It contributes significantly to minimizing the amount of sewage sludge and allows the production of organic fertilizer instead of waste. It is a technologically and economically effective as well as environmentally friendly process. The ATAD installation requires a small area, and the process is carried out in closed tanks. The use of tight reactor structures and interobject wires means that there is no threat to the groundwater and ground surface. The tanks are closed and the elimination of odours is achieved through the use of photocatalytic oxidation devices. The noise emission, in particular due to using aeration equipment, does not exceed 40-50 $\mathrm{dB}$. The aesthetic look of the installation elements makes it easy to adapt them to the surrounding landscape, resulting in their complete harmony with the environment. Due to the possibility of complete insulation, the nuisance of the facilities does not cross the boundaries of the wastewater plot. The use of the described ATAD installations meets the expectations of the operators and facilitates the work, thanks to the equipment of modern and effective devices, the impact of which on the environment is only minimal.

\section{Acknowledgements}

The analyzes were carried out as part of the work No S/WBiIŚ /02/2014 and financed from the funds of the Ministry of Science and Higher Education.

\section{REFERENCES}

1. Antolin M.C., Muro I., Sánchez-Diaz M., 2010, Sewage sludge application can induce changes in antioxidant status of nodulated alfalfa plants, Ecotoxicology and Environmental Safety, vol. 73, 436-442.

2. Bartkowska I., 2013, Sludge as an agent improving soil properties, Journal of Ecological Engineering, 14(2), 63-67.

3. Bartkowska I., 2014, Influence of the sewage sludge stabilisation process on the value of its oxidation reduction potential, Environmental Technology, 35(17), 2160-2166.

4. Bartkowska I., 2015, Drop in dry mass and organic substance content in the process of autothermal thermophilic aerobic digestion, Process Safety and Environmental Protection, vol. 98, 170-175.

5. Borowski S., 2000, Tlenowa stabilizacja termofilowa osadów ściekowych, Ochrona Środowiska, 4(79), 21-25. (in Polish)

6. Heidrich Z., Suszyński A., 2010, Bilansowanie ilości osadów powstających w komunalnych oczyszczalniach ścieków, Gaz Woda i Technika Sanitarna, vol. 2, 35-40. (in Polish).

7. Kelly, H.G., 2006, Emerging processes in biosolids treatment, Journal of Environmental Engineering and Science, vol. 5, 175-186. 
8. Movahedian A.H., Bina B., Moeinian K., 2005, Effects of aeration rate and detention time on thermophilic aerobic digestion of mixed sludge and its dewaterability, International Journal of Environmental Science And Technology, 2(2), 105-111.

9. Nosrati M., Sreekrishnan T.R., Mukhopadhyay S., 2007, Energy Audit, Solids Reduction, and Pathogen Inactivation in Secondary Sludges during Batch Thermophilic Aerobic Digestion Process, Journal of Environmental Engineering, 133(5), 477-484.

10. Parsons B.G., Impacts of temperature and hydraulic retention time on odors produced from autothermal thermophilic aerobic digestion, A thesis submitted in partial fulfillment of the requirements for the degree of master of applied science in the faculty of graduate studies, The University of British Columbia, 2008.

11. Piterina A.V., Bartlett J., Pembroke T.J., 2010a, Evaluation of the Removal of Indicator Bacteria from Domestic Sludge Processed by Autothermal
Thermophilic Aerobic Digestion (ATAD), International Journal of Environmental Research and Public Health, 7(9), 3422-3441.

12. Podedworna J., Heidrich Z., 2010, Kierunki ostatecznego unieszkodliwiania osadów ściekowych, Gaz, Woda i Technika Sanitarna, vol. 3, 25-28. (in Polish).

13. Skowron K., Olszewska H., Pawłowska A., 2011, Ocena wpływu procesu kompostowania na zmiany liczebności populacji grzybów drożdżoidalnych i pleśniowych w osadach ściekowych, Rocznik Ochrona Środowiska, vol. 13, 1485-1506. (in Polish).

14. Zhou J., Mavinic D.S., Kelly H.G., Ramey W.D., 2002, Dewaterability of thermophilically digested biosolids: effects of temperature and cellular polymeric substances, CSCE/ASCE-EWRI Environmental Engineering Conference, Niagara Falls, Canada.

15. Zupančič G.D., ROŠ M., 2008, Aerobic and twostage anaerobic-aerobic sludge digestion with pure oxygen and air aeration, Bioresource Technology, vol. 99, 100-109. 